After the Gircus 
This page intentionally left blank 
English translations of works by Patrick Modiano

From Yale University Press

After the Circus

Paris Nocturne

Pedigree

Suspended Sentences

Also available or forthcoming

The Black Notebook

Catherine Certitude

Dora Bruder

Honeymoon

In the Café of Lost Youth

Lacombe Lucien

Missing Person

Out of the Dark

So You Don't Get Lost in the Neighborhood

The Occupation Trilogy (The Night Watch,

Ring Roads, and La Place de l'Etoile)

Villa Triste

Young Once 
This page intentionally left blank 


\section{After the Circus}

A novel by Patrick Modiano

Translated from the French

by Mark Polizzotti

Yale UNIVERSITY PRESS · NEW HAVEN AND LONDON

\section{A MARGELLOS}


The Margellos World Republic of Letters is dedicated to making literary works from around the globe available in English through translation. It brings to the English-speaking world the work of leading poets, novelists, essayists, philosophers, and playwrights from Europe, Latin America, Africa, Asia, and the Middle East to stimulate international discourse and creative exchange.

English translation copyright @ 2015 by Mark Polizzotti. Originally published as Un cirque passe. @ Editions Gallimard, Paris, 1992. All rights reserved. This book may not be reproduced, in whole or in part, including illustrations, in any form (beyond that copying permitted by Sections 107 and 108 of the U.S. Copyright Law and except by reviewers for the public press), without written permission from the publishers.

Yale University Press books may be purchased in quantity for educational, business, or promotional use. For information, please e-mail sales.press@ yale.edu (U.S. office) or sales@yaleup.co.uk (U.K. office).

Designed by Nancy Ovedovitz.

Set in MT Baskerville type by Tseng Information Systems, Inc.

Printed in the United States of America.

Library of Congress Control Number: 2015940845

ISBN 978-0-300-21589-2 (paper : alk. paper)

A catalogue record for this book is available from the British Library. This paper meets the requirements of ANSI/NIsO Z39-48-1992 (Permanence of Paper).

$\begin{array}{llllllllll}10 & 9 & 8 & 7 & 6 & 5 & 4 & 3 & 2 & 1\end{array}$ 
For my parents 
This page intentionally left blank 
After the Gircus 
This page intentionally left blank 